\title{
Current Dilemmas of the Ethnographer behind the
} Camera

Visual Inquiry and Idiomatic Filmmaking Practices

Dilemmes actuels de l'ethnographe à la caméra

Jonathan Larcher and Noémie Oxley

\section{OpenEdition}

\section{Journals}

Electronic version

URL: http://journals.openedition.org/anthrovision/1572

DOI: 10.4000/anthrovision. 1572

ISSN: 2198-6754

Publisher

VANEASA - Visual Anthropology Network of European Association of Social Anthropologists

Electronic reference

Jonathan Larcher and Noémie Oxley, "Current Dilemmas of the Ethnographer behind the Camera », Anthrovision [Online], 3.2 | 2015, Online since 05 September 2016, connection on 19 April 2019. URL: http://journals.openedition.org/anthrovision/1572 ; DOI : 10.4000/anthrovision.1572

This text was automatically generated on 19 April 2019

(c) Anthrovision 


\title{
Current Dilemmas of the Ethnographer behind the Camera
}

\author{
Visual Inquiry and Idiomatic Filmmaking Practices \\ Dilemmes actuels de l'ethnographe à la caméra
}

Jonathan Larcher and Noémie Oxley

1 The activity of the camera operator, unlike that of the ethnographer, is immediately understandable for the people he encounters (MacDougall, 1979). Even if they do not produce images themselves, the filmed subjects very often know for what purposes they wish to use them. $\mathrm{S} / \mathrm{h}$ needs to come to terms with the normative expectations of his/ her interlocutors, provoked by a greater « accountability » of his/her activity as a filmer and the expansion of video practices among them (Garfinkel, 1967). These expectations relate to what needs to be filmed, in which way, from which position, or for how long. They also refer to the form taken by the images that the ethnographer should return to the people filmed or circulate for them. These transactions, whether they occur during the shooting, the editing, the moment of restitution of the final images, or while the ethnographer with a camera is immersed within the population, all refer to what we have named "the filming relation".

2 The exploration by Frederique Leresche, Marcos Garcia de Teresa and Perrine Poupin of their own video practices during their ethnography share the same quality. They stress the current state of the conditions prevailing the production of images on the field, as well as reveal new ways in considering the visual productions and practices co-existing with that of the ethnographer. These ethnographic works confirm two major transformations: an abundant production of images made possible by small digital cameras; and their rapid dissemination through social networks and other sociotechnical devices. These connected videos and photographs generalize « The groundbreaking, conventions-altering, forms of self-representation by those who have traditionally been objects (and blind spots) of anthropological study: women/natives/ others » (Nichols, 1994, 60). 
These connected images are not anymore only produced by political and cultural activists and conveyed through indigenous media (Ginsburg, 1994; Ginsburg, 2011). They are neither only taken by filmmakers belonging to these groups. These images are also and for an increasing part amateur productions, reflecting more logics of civil society and individual tactics than politically established discourses (Blondeau, Allard, 2007; Christen, 2005; Ginsburg, 2012; Gunthert, 2014).

Distinctively, each case presents practices symptomatic to a particular moment in visual anthropology. In new ways indeed, the ethnographic filmmaker faces the dilemmas of the observer regarding the authorship of the work (and the gaze), the expectations of the filmed subjects, and particular circulations of amateur productions in the context of local visual cultures.

\section{The Fieldwork in Visual Ethnography: Different Forms of Negotiations}

In his films and his work on the filmed observation of social interactions, Christian Lallier shows the ways in which participants to a situation assign rights and duties, which are not directly attributable to a social, cultural, juridical context, but refer for a great part to the relation between the filmant and his filmed subjects. The participants to the filmed situations assign rights and duties to each category of this standardized relational pair.

Christian Lallier demonstrates that the category of the filmant reflects a posture of " petit $^{2}$ ». The " petit » " withdrawn from the world that he represents ${ }^{3}$ " (Lallier, 2009: 128), wishes to report what is at play in an interaction:

"The filmmaker is a "petit » in the way that he does not belong to the « world » of the social relations he observes: he cannot serve the social relation or participate to the success of the ongoing action, and steps in only for his own personal satisfaction, to such extent that his presence is not taken seriously by the participants and has merely an entertaining effect ${ }^{4} »$ (Lallier, 2009 : 127).

With this status of « petit », the « filming observer » explored by Lallier does not threaten the social conventions in the ongoing activity; his interlocutors though do not consider him neither as a resource (Lallier, 2009). Unlike him, Frédérique Leresche, Marcos Garcia de Teresa and Perrine Poupin reveal the dilemmas inherent to the ethnographer with a camera immersed within a group he observes and films. He experiences the difficulties taking ownership of his framing and his gaze, and struggles as he becomes the servant of a relation very often imposed by the filmed subjects. Each author, on the contrary, reacts differently to these ambiguous injunctions. They force them to respond to the solicitations addressed by the filmed subject, as well as claim the singularity of their own gaze. From this perspective, we invited Christian Lallier to dialogue with their works and discuss their theses.

\subsection{The Ethnographer With a Camera: A Threat Or a Resource For the Filmed People?}

Within the limits imposed by this article we will not elaborate on the long history of ethnographic cinema ${ }^{5}$. Yet the authors' video productions seem to indicate an important evolution in the classical and widely studied relation between the filmmaker and his/her 
filmed subjects. The presentation by Nicole Brenez of Clarisse Hahn's avant-garde films at the Cinémathèque Française in 2014, while not focusing directly on documentary practices in ethnography, recounts well the issues at stake within this evolution.

" One could trace a history of contemporary documentary through three shots and three injunctions. In 1971, the shot of the Palestinian woman displaced in a Lebanese refugee camp explaining to the journalists from the California Newsreel, "I do not want you to take my image here - wait before I return to my land, then you can take my image" (We Are the Palestinian People). In 1985, the shot of the defenceless Indian woman surviving on the street in Bombay with her children who hails the filmmaker Anand Patwardhan, claiming that his images will be only useful for him, and by no means for her or her family (Bombay Our City). In 2012, in the archives of 2000 edited by Clarisse Hahn, the shot of the Kurdish communist militant imprisoned in Turkey screaming at her enemy, "Film, bastard, film, show this to the people! I will smash your brain if you don't film" (Prisons. Notre corps est une arme). With these injunctions coming from the bottom of oppression, the oppressed people and combatants reveal the extent to which they control and master the work of images ${ }^{6} »($ Brenez, 2014)

9 The progressive transformation in the negotiation begins with the representation of the filmed people - since they wish to be represented on their grounds - and leads to their control of the filmer's frame and gaze. This represents a challenge to contemporary ethnographic cinema, as well as to the whole anthropological discipline. « Obviously, a difficulty in filming the other arises as soon as the filmer does not recognize himself any more in the position of the "knower ": the only element justifying his position as a filmer would refer to the filmed people's re-appropriation of the filming gaze ${ }^{7}$ ». Developing on such historicity in contemporary ethnographic film would take us away from the matters raised within this special issue. Yet the contributions begin to respond by showing the extents to which the ethnographer with a camera becomes a resource or a threat for the filmed subjects. They expose as well the negotiations (or even the tricks) that are indispensable to defuse certain filming situations.

10 Frédérique Leresche works on the sidelines of musical practice. She knows very well several Swiss musical bands as she has been herself an actress and a singer. This encouraged her when filming to shift her gaze from the ordinary representation of musical practice - limited to " the artistic momentum " of onstage performance or recording session. She preferred to place close relations and familial intimacy at the core of artistic career, and chose to film specifically these activities situated « on the border of artistic practice ». She discovered then that the ethnographer with a camera cannot claim anymore the monopoly of technical knowledge on the device he carries. These technical aspects of the camera in the conversations with the filmed people become indeed " a conveyor in [her] relations with them, allowing [her] to find [her] "place" " in certain situations such as rehearsals. To a different extent, she encounters at first difficulties in acceding to the familiar sphere, due to the presence of her camera. As she strays from discussions on the "artistic momentum ", the negotiations - through numerous exchanges and interviews - become longer and more thorough. Yet within the familiar sphere she encounters firm oppositions from interlocutors, who categorically refuse when she attempts to film private moments. They allow her to observe them, though without filming.

11 Marcos Garcia de Teresa's fieldwork takes place in the Sierra Mazateca, in Mexico. His research focuses on the intricate relationship between political contexts, hallucinogenic mushroom market practices, and horse races. Anthropologists, documentary filmmakers 
and tourists have been visiting the Sierra Mazateca for more than fifty years, and have provided many images especially in relation to indigenous rituals and the consumption and trade of hallucinogenic mushrooms. When he arrived on site, Marcos Garcia de Teresa's hosts immediately requested him to film them. The family of shamans considers him as a symbolic and material resource, helping to attract a touristic clientele looking for authentic shamans, true to the images taken by the first anthropologists. Yet the ethnographer with a camera becomes a threat as he finds himself caught in logics of strong concurrences between shamans, because his images can be used to discredit his interlocutors. Specifically, as a symbolic and economic resource though, the people in the village ask him to film horse races - a common practice before his arrival.

Perrine Poupin explores situations of gathering and encounters during street actions in Moscow. She makes the methodological choice to film in order to observe, this from the beginning of her field survey. She thus focuses on moments of rallying instead of the activity of the militants. The major part of the participants welcomes her presence with a camera without conditions or limits. Her practice indeed falls in with the logics of situations where the practice of filming is generalized: « many activists, journalists and policemen film protests ». Her filming thus belongs to a visual economy in which her presence and her activity contribute to the constitution of the event. Indeed, « being filmed reinforces the activists' sense of belonging to both the protest and to a visible and known group ». While she does not express it in these terms, her involvement in filmed situations becomes a resource and a symbolic pageantry in the eyes of her interlocutors.

\subsection{Tactics of the Filmer}

13 In an unprecedented manner, the debates present the ethnographer with a camera as he faces the demands of the filmed people, and more generally, as he is confronted by his interlocutors to the instrumentalization of his presence. Each contributor attempts then to combine his expectations with a very precise idea of his object of study, and his specific deontological responsibility. The strategies deployed by the scholar become tactics deployed by the filmer as he evolves on the territory of the other. He invests on « a habile use of the time [and] the occasions it offers » - in other words, his practice is " an art of the weak $^{8} \gg$ (de Certeau, 2005: 63, 61).

Frédérique Leresche deploys tactics to avoid discomfort. This includes her own discomfort as on some occasions she films rehearsals and musical practice sessions to keep a countenance. It also includes the discomfort of her interlocutors when she uses her Smartphone instead of her HD camera in the privacy of homes, playing with the more familiar representation of the technical device (Lallier, 2009: 42). Her position of observer is even more embarrassing as she is professionally close to certain people she films. In this context, using the "tool camera" enables her in certain situations to make this distance more acceptable, even if it means that she does not know exactly what to film. Through the use of the camera, finally, she transcends her gender condition on a field characterized by an important gender work hierarchy. Confronted with a " gang of men making guy jokes comparing their instruments ", she becomes a proper interlocutor thanks to her technical device (Leresche, 2014: 155-156). Frédérique Leresche thus kept away these relations of gender domination, intimately experienced during her artistic career. To do so, she used « a varied range of operations through which intelligence, in order to come in contact with its object, faces it in a relation of rivalry, both made of 
connivance and opposition ${ }^{9}$ "(Détienne, Vernant, 1974: 12). By fighting against the internalization of these gender and professional statuses divides prevailing on her fieldwork, she unveils the difficulty for the ethnographer with a camera to position herself as " petit " (Lallier, 2009; Boltanski, Thévenot, 2006) in situations constantly reminding her of her status of dominated.

Marcos Garcia de Teresa accepts his interlocutors' requests and does not ask for any financial contribution - unlike the usual market practices revolving around the production of amateur videos of horse racing. By so doing, he clears his debt towards his hosts as well as earning a greater freedom of movement. He integrates more easily to the village life and distinguishes himself from a tourist, acquiring after negotiations with his interlocutors a status close to an observer. While producing images for them, he observes dimensions of social life of his interest according to his own research project; by exchanging on his images with his interlocutors, he discovers new fields of observation.

Perrine Poupin does not need to negotiate about her filming, as her interlocutors give her all the latitude she wants. Her negotiations, made of « connivance and opposition » focus on the broadcasting of images: she refuses for instance to film reunions to avoid authorities or ultra groups to identify the militants. These tactics prove her attention regarding the Russian State's attempts to map and identify the opposition. Her refusal to show everything contrasts with the use of images made by the militants. The camera is therefore a resource for the ethnographer (Leresche, Garcia de Teresa) or for her interlocutors (Garcia de Teresa, Poupin). Yet Perrine Poupin's carefulness towards the potentially negative re-appropriations of her images, and Marcos Garcia de Teresa's concern towards the possible use of his horse races videos in witchcraft practices reveal how much the images produced by the ethnographer with a camera constitute a threat, not for the social conventions of the situations observed (Lallier, 2009), but for the filmed subjects.

\section{From the Images Produced By the Ethnographer to Image Users Practices: A Mutation in the Field of Visual Anthropology?}

17 In her study of indigenous media, Faye Ginsburg shows the " parallax effect » between points of views of ethnographic films and first people visual productions (Ginsburg, 1995). In this special issue, the contributions go beyond this distinction by focusing first and foremost on other types of productions. Marcos Garcia de Teresa explores the amateur practices of indigenous communities more than the political actions of militants or activists. Perrine Poupin observes the practices of militancy, which do not belong to indigenous political movements. Moreover, the productions of the ethnographer merely co-existed with the more or less professional images produced by his interlocutors. The authors' productions, on the other hand, demonstrate how much the forms, practices and circulation of their images intertwine with their interlocutors'. In an unprecedented manner, their productions unveil the different dimensions defining the visual regimes of a specific social group. In this respect, local practices of images can influence their own visual work (Poupin, Garcia de Teresa), while the negotiations revolving around the visual practices of their interlocutors may impact their own filming (Leresche). Indeed, unlike Bill Nichols' comment that « Being 'on the scene' » allowed « anthropologists to identify 
subsequent distortions in the representations of others » (Nichols, 1994: 68), the debates do not use the supposed authority of ethnographic cinema to criticize inexact, unauthentic, incorrect images. Legitimizing one's own images while demeaning the credibility of any other representation is still a common practice in visual anthropology. The assemblage of television images kept out of frame, at the end of Lucien CastaingTaylor and Véréna Paravel's Leviathan could probably be seen as the latest avatar of this odd habit.

\subsection{The Circulation of Digital Images: New Dilemmas for the Visual Ethnographer}

In the history of ethnographic cinema, the scholar for the major part uses filmmaking as " the arena of an inquiry " (MacDougall, 1979). He conceives his activity within the framework of ethnography, exploring the position of the observer, his relation with the filmed subjects, and the reception of his images by his interlocutors. The contributions show on the contrary the extent to which the ethnographer's involvement implies the consideration of their local visual cultures (Garcia de Teresa, Poupin) as well as the " conditions for visibility» (Deleuze, 1986: 66) socially constructed by a community. Both elements give the authors not only access to the living space of others, but allow them the possibility to film them (Leresche).

Instead of focusing on the " artistic momentum » of the musicians' body and their instruments when filming, which would be expected from a documentary focusing on this subject, Frédérique Leresche observes the people listening, the children playing, and the look of those supervising or teaching. She does not need to negotiate for a long time before the musicians accept to be filmed during rehearsals, recording sessions and concerts. These agreements stress the conditions of visibility socially constructed by the group, who only wishes to show " the best piece ", the " superior part of the activity ${ }^{10}$ ». It is by virtue of this principle that they refuse to be filmed in certain situations « on the border of practice ».

Perrine Poupin adapts the form and broadcasting of her images to her interlocutors': she films short sequences from inside the demonstrations and uploads them on Internet. However she distinguishes her work from these militant productions. She prefers to use sequence shots than editing images with many cuts, and, in her filmmaking, focuses on the morphology of meetings and the negotiations at work, constant in these demonstrations. Throughout their discussions and by observing their images, she notes the lack of « didactic sensibility » of the activists, who film for « their own purpose " and intend their productions for " those who know the history of the action and the mobilisation ${ }^{11} »$. Her images circulate in the same way as the others on digital platforms used by the militants without any concerted broadcasting strategy.

In his video, Marcos Garcia de Teresa reproduces the aesthetics of local productions of horse races. He uses the slow motion effect, the repetition of key moments of the race such as the finishing line, and traditional music chose by her sponsors. His images merge with the visual culture of his interlocutors, notably made of imageries produced by Mexican cultural industries. Differing from indigenous media, there is here no concerted broadcasting strategy. The people uploading these videos on the Internet are most likely " students or teachers who go to Internet cafés or use the computer equipment of their school $^{12} »$. These logics of circulations draw from civil society and individual interests, 
making possible the re-appropriation of these images in witchcraft practices or political contexts.

\subsection{An Ethnography of Visual Regimes Through the Practice of Filming}

The visual ethnographies of Marcos Garcia de Teresa, Frederique Leresche and Perrine Poupin document much more than social situations. They explore dimensions of the visual regimes used by their interlocutors that are central to their amateur productions. Their works encourage us to reconsider in a new light two fields in visual anthropology. The first one involves a filmic ethnography considering the scholar's image production as the principal body of research data, part of this data allowing the production of a documentary film on a particular social situation and lived experience. The second one involves an anthropology of the visual taking as its object the imageries and the material productions of a culture, a given political situation or a given circumstance, in which meaning is produced and reactivated through social relations. However, encounters between these constitutive approaches in visual anthropology are relatively rare (Colleyn, 2012). Through their work on images, the contributions draw a bridge between the study of the conditions for visibility of a given group and the imageries produced and re-used by this group. One can replace the threads outlined in their analyses in the current context of social sciences, encountering mutations both in their objects of study and reading grid following the pictorial turn (Mitchell, 1994) and the material turn. These threads concern at the highest level visual anthropology.

For more than a decade, historians and art historians have been considering their body of data and their historical documentations from an anthropological perspective. It includes scholars exploring the constitution of visual regimes, whether in the construction of Western modern art (StoichiȚă, 2014), the appearance of the « Egyptian moment in the court culture in 16th to 18th century France ${ }^{13}$ " (Asséo, 2009), or the parallel developments in bio-images and genetic engineering in the context of the "War on Terror » (Mitchell, 2011).

The contributors do not limit their analysis of a social situation to their own perspectives. They show how much the " revolutions in digital images " in the 2000s transform the fieldwork of the visual ethnographer and unveil the visual and discursive regimes produced by his/her interlocutors. These transformations affect his/her images, especially in relation to the new conditions for visibility induced by the digital revolutions, the local visual cultures, and the vernacular logics of his/her interlocutors' practices of images. A first major change concerns the filming apparatus. Using light cameras (Poupin) or smartphones (Garcia de Teresa) became general in certain situations, where filming is now an ordinary practice and the presence of the camera much more commonly accepted. This seems to confirm a movement of « liberation of subjectivities ${ }^{14}$ " (Cardon, 2010: 40), otherwise observed on Internet. However, while the discourses claiming the end of privacy on Internet claim that everything is now exposed and the frontier between public and private space has disappeared, social networks users continuously negotiate the terms defining this separation (Casilli, 2013). The oppositions encountered by Frederique Lereche when she wishes to film the intimacy of the musicians' life stress the importance of these boundaries in the visual ethnography field. The effect of the greater availability of these digital tools to film, photograph, or upload 
on the Internet is not unilateral; it should not lure into thinking that the filmer can film anything. It seems on the contrary that there is a greater opposition to the presence of the ethnographer now, in situations where recently it could still be more easily accepted. Another change refers to the authors' ability to dialog, in their productions, with local visual cultures. In his productions intended for his interlocutors, the forms used by Marcos Garcia de Teresa borrowed from the visual cultures of the filmed subjects. By doing so, he discovered their vernacular practices of distortion of a nationalist ideology imagery embodied in the charro, a figure promoting in cultural industries « a model of masculinity relying on working in the fields, breeding horses and gambling activities ». Through her involvement as ethnographer with a camera, Perrine Poupin fits in «the "wired" and connected micro-climate giving a first role to digital forms of publicizing ", this despite the fact that her visual productions differ formally (editing, scale value and duration of shots). This allows her to critically address these images.

She analyses them by the yardstick of a « media strategy " inherited from the USSR, notably in regards to the impact of images on the "masses ». Negotiating in filmed situations and within a highly-connected context, the ethnographers with a camera thus access the conditions for visibility constructed by the social group they observe. The traces of these conditions are also present in the images that he decides to dismiss, sometimes almost censuring himself. As Frédérique Leresche suggests, «there are things that I say in writing that I do not wish to say through images ${ }^{15} »$. For the same reasons, the ethnographers with a camera access the ways and means of circulation of their interlocutors' images, as well as the discursive regimes coming with their reception (Poupin). These practices do not only obey unilateral logics - for instance indigenous media - but refer to individual strategies - navigating between research for prestige, defamation, and witchcraft - to which the ethnographer adapt his own representation apparatus (Garcia de Teresa).

\section{Conclusion}

In their contributions, the authors recount situations relatively unseen in visual anthropology, yet probably becoming soon common for an ethnographer with a camera and strongly affecting his production of images. The debates make a sidestep in regards to a collaborative and shared conception of visual ethnography. They show in which ways the people filmed negotiate more and more their representation and the control of the frame with the filmmaker. Confronted to these clearly formulated expectations, the filmer is sometimes forced to respond with tactics and tricks in order to claim the singularity of his/her gaze. Furthermore, the works of Marcos Garcia de Teresa and Perrine Poupin stress the increase of images produced by interlocutors during fieldwork and uploaded on social networks and sharing digital platforms. It becomes impossible to consider the visual ethnographer's productions without studying in depth the vernacular visual and digital cultures of the filmed people. This also includes recounting the relations between the high exposition of certain social situations and the difficult access to their intimacy. On this specific point, Frédérique Leresche's contribution raises the hypothesis of a greater difficulty of access to certain areas of social life when the ethnographer with a camera does not impose the authorship of his gaze.

Her self-ethnography and the observations of Marcos Garcia de Teresa and Perrine Poupin confirm the specific constraints bearing weight on the filming relation, as well as 
the changes in the way in which it is today instrumentalized by the respondents. The power relationship between the ethnographer with a camera and the people filmed has become more complex and has expanded. It has become more complex because the balance of power may sometimes be totally reversed, when for instance Frédérique Leresche cannot overcome her dominated position assigned by her fieldwork, making any filming extremely difficult. This power relationship has expanded, especially since the ethnographer needs to observe as well the ways in which his images can circulate on Internet, making him a threat for the filmed people.

The practices of connected images determine in part the established relationship between the filmed subjects and the ethnographer with a camera. The contributions thus stop before venturing into another field of research exploring online sociabilities and online images practices. From this perspective, the encounter between research fields until now separated such as visual ethnography, anthropology of medias (Ginsburg, AbuLughod, Larkin, 2002; Postill, Peterson, 2009; Peterson, 2003) and digital anthropology (Casili, 2010; Horst, Miller, 2012; Peterson, 2011) seem inevitable.

\section{BIBLIOGRAPHY}

Asséo, Henriette, 2009. Travestissement et divertissement. Bohémiens et Égyptiens à l'époque moderne. Les Dossiers du Grihl, n², http ://dossiersgrihl.revues.org/3680 [page visited: 26.6.2016].

Banks, Marcus and Jay Ruby, 2011. Introduction: Made to Be Seen. Made to be Seen: Perspectives on the History of Visual Anthropology. Chicago/London: The University of Chicago Press, pp.1-18.

Blondeau, Olivier, Allard Laurence, 2009. Devenir Média. L'activisme sur internet entre défection et expérimentation. Paris: Éditions Amsterdam.

Brenez, Nicole, 2014. Clarisse Hahn ou "Si tu me filmes pas, je t'explose la cervelle". Présentation du Cycle Clarisse Hahn, Séances d'avant-garde à la Cinémathèque Française. http://jousseart.com/wpcontent/uploads/2014/03/01-Clarisse-Hahn-Cin\%C3\%A9math\%C3\%A8que-fran\%C3\%A7aiseILL-2-2.pdf [page visited: 26.6.2016].

Cardon, Dominique, 2010. La Démocratie Internet. Promesses et limites. Paris: Seuil, coll. La République des Idées.

Casilli, Antonio A., 2010. Les Liaisons numériques. Vers de nouvelles sociabilités ?.Paris: Seuil.

Casilli, Antonio A., 2013. Contre l'hypothèse de la « fin de la vie privée ». Revue française des sciences de l'information et de la communication, 3, http://rfsic.revues.org/630 [page visited: 26.6.2016].

Christen, Kimberly, 2005. Gone digital: Aboriginal remix and the cultural commons. International Journal of Cultural Property, 12, pp.315-45.

Colleyn, Jean-Paul, 2012. Champ et hors champ de l'anthropologie visuelle. L'Homme. vol.3, $\mathrm{n}^{\circ}$ 203-204, pp.457-480.

de Certeau, Michel, 2005 (1990). L'Invention du quotidien. 1. Arts de faire. Paris: Gallimard, folio. 
Deleuze, Gilles, 1986. Foucault. Paris: Éd. de Minuit.

Détienne, Marcel, Vernant Jean-Pierre, 1974. Les Ruses de l'intelligence. La mètis des grecs. Paris: Flammarion.

Garfinkel, Harold, 2007 (1967). Recherches en ethnométhodologie. Paris: PUF.

Ginsburg, Faye, 1994. Embedded aesthetics: Creating a discursive space for indigenous media. Cultural Anthropology, vol. 9 n², pp.365-382.

Ginsburg, Faye, 1995. The Parallax Effect: The Impact of Aboriginal Media on Ethnographic Film. Visual Anthropology Review, vol. 11, n 2, pp.64-76.

Ginsburg, Faye, 2011. Native Intelligence. A Short History of Debates on Indigenous Media and Ethnographic Film. Banks M., Ruby J., (ed), Made to be seen. Historical Perspectives on Visual Anthropology, Chicago/London, The University of Chicago Press, pp.234-255.

Ginsburg, Faye, 2012. Disability in the Digital Age. Horst Heather A., Miler Daniel (ed.), 2012. Digital Anthropology. London/New York: Berg, pp.101-126.

Ginsburg, Faye, Abu-Lughod Lila, Larkin Brian (eds), 2002. Media Worlds. Anthropology on New Terrain, Berkeley/Los Angeles/London: University of California Press.

Gunthert, André, 2014. L'image conversationnelle. Les nouveaux usages de la photographie numérique. Études photographiques. $\mathrm{n}^{\circ} 31$, pp.54-71.

Horst Heather A., Miler Daniel (ed.), 2012. Digital Anthropology. London/New York: Berg

Lallier, Christian, 2009, Pour une anthropologie filmée des interactions sociales. Paris: Archives contemporaines.

Leresche, Frédérique. 2014. La caméra comme vecteur relationnel. Tessituras. Vol. 2, n², pp.

152-161.

MacDonald, Scott, 2013. American Ethnographic Film and Personal Documentary. The Cambridge Turn. Los Angeles/London: University of California Press.

MacDougall, David, 1979 (1975). Au-delà du cinéma d'observation. de France C., Pour une anthropologie visuelle. Paris, La Haye, New York: Mouton éditeur/Cahiers de l'Homme, pp.89-104.

Mitchell, William J. Thomas, 1994. The Pictorial Turn. Picture Theory: Essays on Verbal and Visual Representation. Chicago: University Chicago Press, pp.11-34.

Mitchell, William J. Thomas, 2011. Cloning Terror. The War of Images, 9/11 to the Present. Chicago/ London: The University of Chicago Press.

Nichols, Bill, 1994 (1992). The Ethnographer's Tale. Taylor, Lucien, Visualizing Theory. Selected Essays from V.A.R. 1990-1994. New York/London: Routledge, pp.60-83.

Pavsek, Christopher, 2015. Leviathan and the Experience of Sensory Ethnography. Visual Anthropology Review, Vol. 31, n¹, pp.4-11.

Peterson, Mark Allen, 2003. Anthropology and Mass Communication. Media and Myth in the New Millennium. New York/Oxford: Berghahn Books.

Peterson, Mark Allen, 2011. Toward an Anthropology of Connections. Connected in Cairo. Growing up Cosmopolitan in the Modern Middle East. Bloomington/Indianapolis: Indiana University press, pp.1-27.

Postill, John and Mark Allen Peterson, 2009. What is the point of media anthropology? Social Anthropology 17(3), pp.334-344. 
StoichiȚă, Victor I., 2014. L'image de l'Autre. Noirs, Juifs et Musulmans et « Gitans » dans l'art occidental des Temps modernes. Paris: Éditions Hazan, Louvre Éditions, La Chaire du Louvre.

Watson, Rod, 1994. Catégories, séquentialité et ordre social. Un nouveau regard sur l'œuvre de Sacks. Fradin, Bernard, Quéré, Lous, Widmer, Jean, (dir.), L'Enquête sur les catégories. De Durkheim à Sacks. Paris: Éd. de l'EHESS, pp.151-184.

\section{NOTES}

1. The expression "Filming Relation" refers to the title of the visual ethnography workshop organised within the "Rencontre Annuelles de l'Ethnographie" Conference, at the EHESS in Paris in november 2014. This pluridisciplinary conference gathered twelve panels around the different themes and practices defining ethnography.

2. Here Christian Lallier borrows the term from Luc Boltanski and Laurent Thévenot, developed in their work on the economies of worth. Luc Boltanski, Laurent Thévenot. On Justification. Economies of Worth. Princeton: Princeton University Press. Translated by Catherine Porter, 2006 (1991).

3. « petit [...] placé en retrait du monde qu'il représente »( Lallier, 2009 : 128). Authors' own translation.

4. "Le cinéaste est un "petit" au sens où il n'appartient pas au "monde" des rapports sociaux qu'il observe : il ne peut servir la relation sociale, participer à la réussite de l'action en cours et n'intervient qu'au bénéfice de sa seule satisfaction personnelle, de sorte que sa présence n'est pas prise au sérieux par les participants et ne produit qu'un effet divertissant » (Lallier, 2009 : 127). Authors' own translation

5. See Nichols, 1994; Banks, Ruby, 2011; MacDonald, 2013

6. "On pourrait tracer un historique du documentaire contemporain à partir de trois plans et trois interpellations. En 1971, celui de la Palestinienne déplacée dans un camp libanais expliquant aux membres du California Newsreel, «Je ne veux pas que vous preniez mon image ici - attendez que je retourne sur ma terre, alors vous pourrez prendre mon image » (We Are the Palestinian People). En 1985, celle de l'Indienne démunie qui survit sur un trottoir de Bombay avec ses enfants et interpelle le cinéaste, Anand Patwardhan, en lui reprochant que ses images lui serviront à lui mais en rien à elle ni à sa famille (Bombay Our City). En 2012, dans les archives de 2000 montées par Clarisse Hahn, celui de la militante communiste kurde emprisonnée en Turquie hurlant à son ennemi, «Filme, bâtard, filme, montre ça au peuple ! Si tu me filmes pas, je t'explose la cervelle!» (Prisons - Notre corps est une arme). Dans ces injonctions venues du fin fond de l'oppression, se révèle à quel point les opprimés et les combattants maîtrisent le travail des images." (Brenez, 2014). Authors' own translation.

7. Christian Lallier. Mails aux auteurs, 13 novembre 2014. "À l'évidence, se pose une difficulté à filmer l'autre dès lors que le filmant ne se reconnaît plus dans une position de "sachant" : la réappropriation du regard-caméra par le filmé deviendrait alors la seule justification de la place du filmant", Authors' own translation.

8. "sur une habile utilisation du temps [et] des occasions qu'il présente [...] un art du faible » (de Certeau, 2005: 63, 61). Authors' own translation.

9. «[...] gamme variée d'opérations par lesquelles l'intelligence, pour entrer en contact avec son objet, se pose en face de lui dans un rapport de rivalité, fait à la fois de connivence, et d'opposition » (Détienne, Vernant, 1974: 12). Authors' own translation

10. Frédérique Leresche. Interview with the authors, 21 March 2015

11. Perrine Poupin. Interview with the authors, 10 March 2015

12. Marcos Garcia de Teresa. Letter to the authors, 21 March 2015. 
13. « moment égyptien dans la culture de cour du XVIème au XVIIIème siècle en France » (Asséo, 2009). Authors' own translation.

14. « libération des subjectivités » (Cardon, 2010: 40). Authors' own translation.

15. Frédérique Leresche. Interview with the authors, 21 March 2015.

\section{ABSTRACTS}

The three studies of this issue present the ethnographer with the camera in new situations. Previously expressed by filmmakers and political critics of the documentary film, the desire for genuine parity is now demanded by the people who are filmed. The ethnographer with the camera finds him/herself in a paradoxical situation on the field. Image practices are prevalent, yet his/her position of observer is not necessarily evident. Moreover, as his/her interlocutors master the logics of circulation of images, new negotiations on the activity of the filmmaker arise. More than practical choices, such transactions engage with core issues in filmed and visual anthropology.

Les trois études de ce numéro présentent l'ethnographe à la caméra dans des situations inédites. Jusqu'alors exprimé par des cinéastes et des critiques politiques du film documentaire, le souhait d'une véritable parité est maintenant exigé par les personnes filmées. L'ethnographe à la caméra se retrouve sur le terrain dans une situation paradoxale: les pratiques de l'image sont répandues sans que la position de l'observateur ne soit forcément nécessaire ou évidente. Bien plus encore, la maîtrise des logiques de circulation des images par ses interlocuteurs entraîne de nouvelles négociations autour de l'activité du filmeur. Plus que des choix pragmatiques, ces transactions engagent des problématiques aux fondements de l'anthropologie filmée et d'une anthropologie du visuel.

Los tres estudios que conforman este número presentan el etnógrafo o etnógrafa investigando con cámara delante de situaciones inéditas. El deseo de una auténtica paridad, hasta hace poco solo reclamado por cineastas y por la crítica política del cine documental, es ahora exigido por las personas filmadas. El etnógrafo o etnógrafa con camara se encuentra en una situación paradójica: con la expansión de las prácticas relativas a la imagen parece que la posición del observador no es ni evidente ni tan siquiera necesaria. Es más, el dominio de la lógicas de circulación de las imágenes por parte de los interlocutores conlleva un conjunto de nuevas negociaciones alrededor de la actividad del cineasta. Más allá de las decisiones de carácter práctico, estas transacciones plantean nuevas problemáticas sobre los fundamentos mismos de la antropología fílmica y de la antropología de lo visual. 
INDEX

Mots-clés: Ethnographie visuelle, film ethnographique, régime visuel, culture visuelle, indigenous media, anthropologie numérique

Keywords: visual ethnography, ethnographic film, visual regime, visual culture, indigenous media, digital anthropology

Palabras claves: Etnografía Visual, Cine Etnográfico, Régimen Visual, Cultura Visual, medios Indígenas, Antropología Digital

\section{AUTHORS}

JONATHAN LARCHER

École des Hautes Études en Sciences Sociales (EHESS), Centre de Recherches sur les Arts et le Langage (CRAL)

larcherj@hotmail.fr

NOÉMIE OXLEY

École des Hautes Études en Sciences Sociales (EHESS), Centre de Recherches sur les Arts et le Langage (CRAL)/Goldsmiths University

noemioxley@yahoo.com 